\title{
Advances in stem cell therapy for spinal cord injury
}

\author{
Andrea J. Mothe and Charles H. Tator
}

Toronto Western Research Institute and Krembil Neuroscience Centre, Toronto Western Hospital, Toronto, Ontario, Canada.

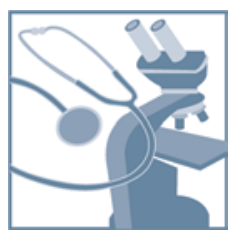

Spinal cord injury (SCI) is a devastating condition producing great personal and societal costs and for which there is no effective treatment. Stem cell transplantation is a promising therapeutic strategy, though much preclinical and clinical research work remains. Here, we briefly describe SCI epidemiology, pathophysiology, and experimental and clinical stem cell strategies. Research in stem cell biology and cell reprogramming is rapidly advancing, with the hope of moving stem cell therapy closer to helping people with SCI. We examine issues important for clinical translation and provide a commentary on recent developments, including termination of the first human embryonic stem cell transplantation trial in human SCI.

\section{Introduction}

Spinal cord injury (SCI) is a devastating condition, with sudden loss of sensory, motor, and autonomic function distal to the level of trauma. Despite major advances in the medical and surgical care of SCI patients, no effective treatment exists for the neurological deficits of major SCI (1). Current treatment includes surgery to decompress and stabilize the injury, prevention of secondary complications, management of any that do occur, and rehabilitation. Unfortunately, neurological recovery is limited, and most SCI patients still face substantial neurological dysfunction and lifelong disability. Stem cell therapy offers several highly attractive strategies for spinal cord repair, including replacement of damaged neuronal and glial cells, remyelination of spared axons, restoration of neuronal circuitry, bridging of lesion cavities, production of neurotrophic factors, antiinflammatory cytokines, and other molecules to promote tissue sparing and neovascularization, and a permissive environment for plasticity and axonal regeneration. This review builds on several excellent previous reviews (2-8) and discusses the incidence and pathophysiology of SCI as well as the key experimental and clinical stem cell strategies for SCI.

Epidemiology, etiology, incidence, and prevalence of $\mathrm{SCl}$ Worldwide, the annual incidence of SCI is $15-40$ cases per million people (9). In Canada, the Rick Hansen Institute estimates there are currently 85,000 people living with SCI, with more than 4,000 new cases per year (10), and in the United States, the Christopher and Dana Reeve Foundation estimates a prevalence of over 1 million patients with SCI and more than 12,000 new cases each year (11).

The primary causes of traumatic SCI are motor vehicle crashes, sports and recreation injuries, falls at home, and trauma at work (12). In young adults, males are four times more likely than females to sustain an SCI (13). Injury incidence shows a bimodal distribution, with the highest incidence in adolescents and young adults, with more than half aged $16-30$ years old (10). The second incidence peak is in older adults, primarily as a result of falls, and the aging population has increased the average age of injury.

Conflict of interest: The authors have declared that no conflict of interest exists. Citation for this article: J Clin Invest. 2012;122(11):3824-3834. doi:10.1172/JCI64124.

\section{Clinical trial design and management of $\mathrm{SCl}$}

Assessment of therapy in patients has improved markedly due to the development of the American Spinal Injury Association (ASIA) grading scale and quantitative scores of sensory and motor function now used worldwide to assess the severity of SCI and response to treatment (1). The ASIA Impairment Scale (AIS) ranges from $A$ to $\mathrm{E}$, where $\mathrm{A}$ is a complete SCI and $\mathrm{E}$ denotes normal sensory and motor function. Acute treatment often involves surgical management, such as decompression, spinal stabilization, or realignment of displaced vertebrae (14) to prevent further injury from impingement on the spinal cord. Acutely injured patients often require intensive care monitoring to treat cardiovascular instability and respiratory insufficiency. Currently, there is limited pharmacotherapy for SCI patients. Methylprednisolone demonstrated some neuroprotective effects in early experimental and clinical studies $(15,16)$, but its use is controversial because of limited efficacy and harmful side effects. Many SCI centers have stopped using steroids (17). Other neuroprotective agents with promising results in experimental animals are now being investigated in clinical SCI trials, including riluzole, a sodium channel blocker, and minocycline, an antiinflammatory agent $(1,18)$. However, neuroprotective agents alone may be insufficient to promote repair in major SCI where there is extensive tissue loss.

\section{Pathophysiology of SCl}

The most frequent type of traumatic SCI is acute compression of the spinal cord (12). Usually, some neurological tissue is preserved, particularly in the subpial region $(19,20)$. The primary mechanical trauma causes necrosis, edema, hemorrhage, and vasospasm. A cascade of secondary pathophysiological mechanisms is induced, including ischemia, apoptosis, fluid and electrolyte disturbances, excitotoxicity, lipid peroxidation, production of free radicals, and an inflammatory response, resulting in further damage due to swelling and blood flow reduction (21). Ultimately, a large fluidfilled cavity or cyst forms in the center of the cord, surrounded by a subpial rim containing some preserved axons, many of which are demyelinated (Figure 1). Hypertrophic astrocytes, macrophages, and other cells secrete extracellular matrix and inhibitory molecules that constitute the glial scar, resulting in a physical and chemical barrier to regeneration (22). 


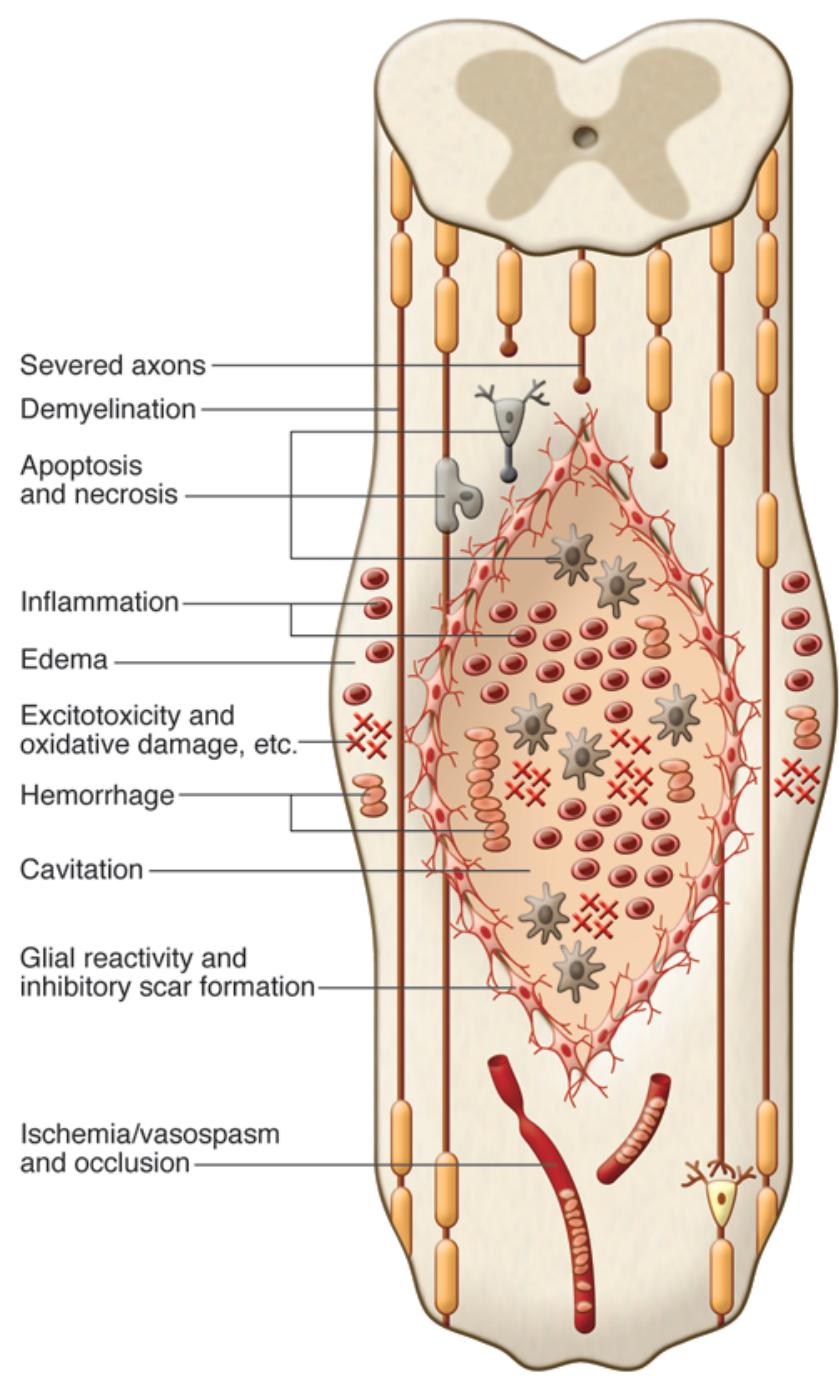

Some experimental rat models of SCI reproduce the typical pathology of human SCI, including the extradural compression, contusion, and crush models in rats (23). SCI is classified depending on the time elapsed from the initial injury: acute, within several days of SCI; subacute, one to two weeks after injury; or chronic, four weeks or more after injury. As discussed below, experimental cell transplantation strategies have generally been more effective in the subacute stage compared with the acute stage or the chronic stage, characterized by glial scarring and other inhibitory factors.

\section{General features of cell therapy for $\mathrm{SCl}$}

Cell therapy is a promising strategy for SCI, and preclinical models demonstrate that cell transplantation can ameliorate some secondary events through neuroprotection and also restore lost tissue through regeneration. Pioneering work in cell therapy began in the late 1970s when Aguayo's group showed that peripheral nerve grafts promoted regeneration of CNS axons (24) and Reier's group showed that grafted fetal spinal cord supported regrowth of host axons (25). Since then, numerous experimental cell transplantation strategies have produced regeneration and partial recovery (2-7). Here, we describe several stem cell-based strategies for experimental and clinical SCI, including the use

\section{Figure 1}

Pathophysiology of SCl. The diagram shows a composite of pathophysiological events occurring after $\mathrm{SCl}$, including the acute (e.g., edema and hemorrhage), subacute (e.g., inflammation), and chronic (e.g., cavitation) phases. The primary and secondary injury mechanisms involve edema, hemorrhage, inflammation, apoptosis, necrosis, excitotoxicity, lipid peroxidation, electrolyte imbalance, ischemia/vasospasm, and blood vessel occlusion. Oligodendrocytes and neurons die, resulting in axonal demyelination and disruption of synaptic transmission. In the subacute and chronic phases, a fluid-filled lentiform-shaped cavity or cyst forms in the center of the cord, with surrounding hypertrophic astrocytes and macrophages. These and other cells secrete extracellular matrix and inhibitory molecules, such as chondroitin sulfate proteoglycans (CSPG), which compose the glial scar, resulting in a physical and chemical barrier to regeneration.

of ES cells, mesenchymal stem cells (MSCs) such as BM-derived stromal cells (BMSCs), neural stem/progenitor cells (NSPCs), and induced pluripotent stem cells (iPSCs) (Figure 2). Transplantation of other cell types, including Schwann cells, olfactory ensheathing glia, genetically modified neurotrophin-expressing fibroblasts, and activated macrophages, have been the subject of other recent reviews $(2-4,7,8)$.

\section{Definition and rationale for stem cells}

A stem cell, by definition, continuously proliferates and asymmetrically divides to self renew and generate daughter cells committed to differentiation. In contrast, progenitor cells demonstrate a limited proliferative capacity and differentiation potential. Several mechanisms for recovery have been proposed, depending on the cell type, including replacement of oligodendrocytes or neurons, remyelination of spared axons, restoration of neuronal circuitry, enhanced preservation of host neuronal and glial cells, increased expression of neurotrophins/cytokines by transplanted or host cells, promotion of angiogenesis, bridging of cysts or cavities, reduced inflammation or gliosis, stimulation of endogenous precursor cells, and creation of a favorable environment for plasticity and axonal regeneration (Figure 3). In most studies, the exact mechanisms of improvement were not completely defined.

\section{ES cells}

ES cells are pluripotent cells derived from the inner cell mass of developing blastocyst embryos that can differentiate into nearly all cell types (26). Human ES cells are typically obtained from preimplantation or blastocyst-stage embryos created during in vitro fertilization procedures and can also be generated by somatic cell nuclear transfer or parthenogenetic activation of eggs. Transplanted ES cells will form teratomas, and thus, ES cells must be predifferentiated prior to grafting. Protocols have been developed to differentiate ES cells into neural precursors (27-30) and specific neuronal (30-32) and glial lineages $(33,34)$. Predifferentiated mouse ES cells transplanted into the injured rat spinal cord differentiated into neurons and glia and showed partial functional recovery (35). As noted above, SCI causes extensive demyelination and oligodendrocytes are particularly vulnerable to apoptosis. ES cells predifferentiated into oligodendrocyte progenitor cells (OPCs) remyelinated spared axons and improved recovery when transplanted subacutely into the injured rat spinal cord $(36,37)$.

The advantage of ES cells is that they can be propagated in vitro almost indefinitely, since they retain high telomerase activity. However, it has been difficult to generate high-purity lineage- 


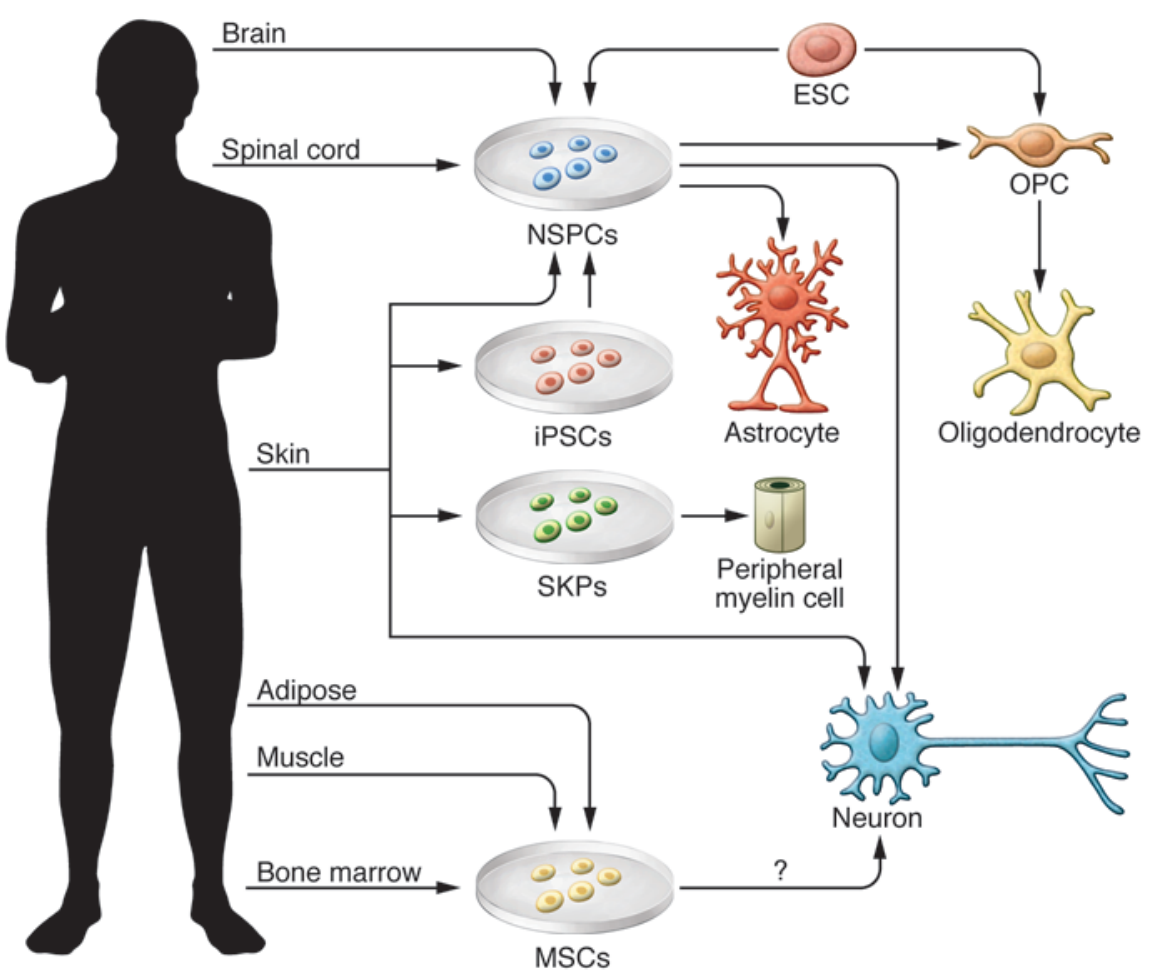

\section{Figure 2}

Sources of stem cells for transplantation into the injured spinal cord. This illustration shows various tissue sources of stem cells, including NSPCs, iPSCs, SKPs, MSCs, ES cells (ESC), and direct conversion methods to yield neural cells for transplantation. NSPCs can be isolated from the fetal and adult brain and spinal cord and differentiated into progenitor cells, such as OPCs and mature oligodendrocytes, or astrocytes or neurons depending on culture conditions and exposure to growth factors. ES cells follow a default pathway to neural cells, and specific conditions can promote OPC generation. MSCs can be derived from a variety of tissues, including BM, umbilical cord, adipose tissue, muscle, and dental pulp from deciduous baby teeth. In culture, MSCs have shown properties of neural cells. Fibroblasts from the skin can be reprogrammed using various methods into iPSCs, which are then directed along a neural lineage. Recent studies have directly converted fibroblasts to neurons and NSPCs, bypassing the pluripotent stage. specific cell lines without karyotypic abnormalities. The concerns with transplantation of ES cell-derived neural cells for SCI are the ethical issues of cell derivation and the possibility of tumorigenesis due to incomplete or aberrant differentiation resulting in the formation of nonneural cells (Table 1).

Based on promising preclinical data of human ES cell-derived OPC transplants in rodent SCI models $(36,37)$, the US Food and Drug Administration (FDA) approved the first human ES cell trial in 2009. This phase I safety trial in SCI sponsored by Geron Corp. began in 2010 after further preclinical safety data were obtained concerning abnormal cyst formation in transplanted animals. The GRNOPC1 cell line (human ES cell-derived OPC) was transplanted subacutely (one to two weeks after injury) directly into the spinal cord of ASIA A patients with complete thoracic SCI. Patients received 2 million cells and were immunosuppressed for the first two months following transplantation. In 2011, Geron discontinued this trial due to funding challenges. No safety issues were reported in the five patients who received GRNOPC1 transplants, but complete results have not been published (Table 2).

\section{NSPCs}

NSPCs are multipotent cells committed to the neural lineage that can self renew and be readily expanded in vitro. NSPCs are typically grown as free-floating neurospheres in serum-free medium supplemented with EGF and FGF-2. Neurospheres are $3 \mathrm{D}$ aggregates comprising a mixture primarily of progenitor cells, a small percentage of stem cells, and small numbers of more differentiated cell types over multiple passages in culture. The neural stem cells respond to the growth factors in the culture medium and selectively proliferate in suspension to form neurospheres. When these cells are plated in growth factor-free medium containing serum, they differentiate into neurons, oligodendrocytes, and astrocytes.
NSPCs are found in both fetal and adult CNS (38). The isolation of adult neural stem cells in mammals was first reported in 1992 by Reynolds and Weiss (39). NSPCs reside within specific niches in the adult CNS, including the subventricular zone lining the lateral ventricles of the forebrain $(40,41)$, the dentate gyrus of the hippocampus (42), and the region of the central canal of the spinal cord (43). Multipotential, self-renewing NSPCs can be isolated and cultured from the adult rodent spinal cord when the cultured tissue includes regions of the central canal $(44,45)$. We have shown that these NSPCs primarily differentiate into oligodendrocytes in vitro (46) and in vivo $(47,48)$. Transplantation of these NPSCs into SCI rats promoted functional recovery with neuroprotective and neuroregenerative effects (49-51). Most studies with transplanted NSPCs have shown modest recovery of the injured spinal cord $(3,7)$, although allodynia was associated with astrocytic differentiation of grafted NSPCs (49). Adult mouse brain-derived NSPCs transplanted into the injured rat spinal cord with concomitant infusion of growth factors promoted oligodendrocyte differentiation of the grafted NSPCs, remyelination, and improved locomotor function $(52,53)$. NSPCs derived from fetal rat spinal cord differentiated into neurons that integrated into the injured cord and improved recovery (54), and transplanted NSPCs combined with valproic acid administration promoted neuronal differentiation, resulting in restoration of disrupted neuronal circuitry and enhanced recovery (55). NSPCs have also demonstrated some immunomodulatory and pathotropic ability by homing toward damaged tissue $(56,57)$ as well as secreting various neurotrophic factors and cytokines (58-60).

Most experimental SCI studies with NSPC transplants have involved rodent cells because human stem cells were either not available or difficult to grow. Human NSPCs have been isolated from fetal brain and spinal cord from aborted fetuses (61-65) and from adult brain from surgical biopsy specimens and post- 


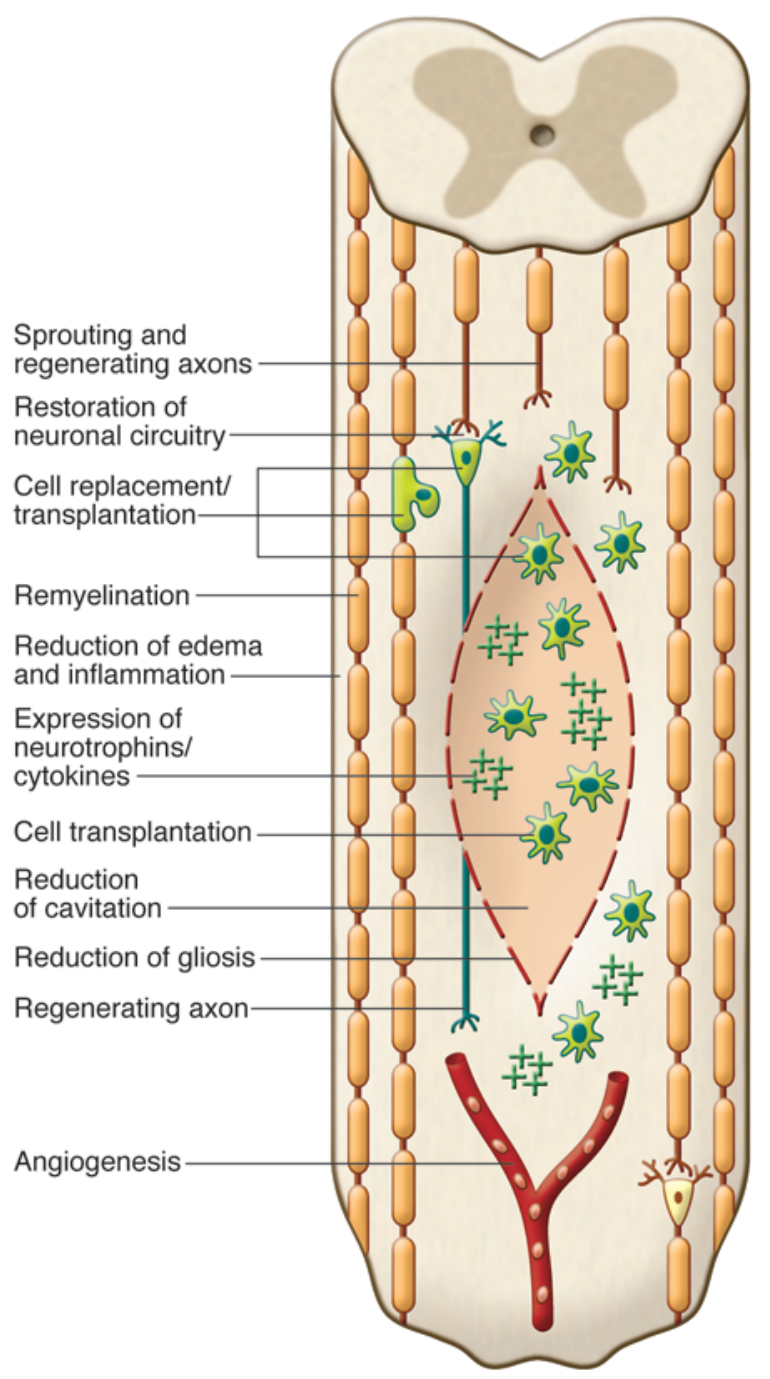

mortem tissue (66-69). Recently, we demonstrated that selfrenewing multipotent NSPCs can be passaged from the adult human spinal cord of organ transplant donors and that these cells differentiate into both neurons and glia following transplantation into rats with SCI (70). Stem cells isolated from the human fetal brain were transplanted into NOD/SCID mice with SCI, and the grafted cells expressed neural differentiation markers and improved recovery $(71,72)$. Extensive neuronal differentiation of human fetal NSPC grafts was reported after transplantation into the adult rat spinal cord (73). In addition, human fetal brain NSPCs (modified to express galectin-1) transplanted subacutely into the contused cervical spinal cord of adult common marmosets produced significantly greater grip strength than controls (74).

A registry of government and privately supported clinical trials from all countries is available (http://www.clinicaltrials.gov). Table 2 summarizes completed trials of stem cell therapy for SCI; Table 3 indicates ongoing trials. Recently, Stem Cells Inc. started a phase I/II (safety/efficacy) trial in Switzerland involving transplantation of human fetal brain stem cells into ASIA A-C patients with thoracic SCI. Currently, this is the only human trial involving NSPCs for SCI, and these patients require immu-

\section{Figure 3}

Potential mechanisms of spinal cord repair following stem cell transplantation. The diagram shows some of the potential mechanisms of repair after transplantation of stem cells into the injured cord. Potential mechanisms include replacement of oligodendrocytes or neurons by transplanted cells (shown in green), remyelination of spared axons, restoration of neuronal circuitry by a new synapse with a transplanted neuron that gives rise to a newly regenerated axon, enhanced preservation of host neuronal and glial cells, for example, by secreted neurotrophins from transplanted cells, promotion of angiogenesis, bridging of the cyst/cavity by transplanted cells, reduction of inflammation or gliosis, stimulation of endogenous precursor cells, and creation of a favorable environment for plasticity and axonal regeneration.

nosuppression. Thus, human NSPCs have certain drawbacks, including ethical concerns about fetal-derived cells, difficulties in expanding adult-derived cells to clinically sufficient numbers, and unavailability of autologous sources.

\section{Skin-derived precursors}

An accessible, potentially autologous source of precursor cells for transplantation is skin-derived precursors (SKPs) residing within the dermis of rodents and humans, as described by Miller and other groups (75-77). SKPs are generated during embryogenesis, persist into adulthood, and share characteristics with embryonic neural crest stem cells, producing both mesodermal progeny and peripheral neurons and Schwann cells (78). SKPderived Schwann cells transplanted into SCI rats showed lesion sparing, remyelination of spared axons with peripheral myelin, and, unlike other sources of Schwann cells, provided a conducive environment for axonal growth into the lesion, but with limited functional recovery (79).

\section{HSCs and MSCs}

Adult BM contains several different stem cell populations of nonneural origin, including HSCs and MSCs. HSCs are self-renewing adult stem cells found mainly in the BM that differentiate into blood and immune cells. In the early 1960s, James Till and Ernest McCulloch observed that BM cells injected into irradiated mice grew as colonies of cells in their spleens, and each colony grew from a single cell (80), now known as a stem cell. These Canadian scientists are recognized as the founders of HSC research. HSC transplantation has now been used for decades to treat blood cancers and other blood disorders (81).

HSCs are identified based on their expression of distinct cellsurface markers and nonadherence to plastic in culture. Typically, erythrocytes and platelets are separated from BM yielding the mononuclear cell fractions (MNCs) comprising HSCs and nonhematopoietic cells, including monocytes, macrophages, endothelial progenitor cells, and small numbers of MSCs. The advantages of HSCs or BM-derived mononuclear cells (BM-MNCs) are that they can be autologously derived and that they have a record of safety in humans. The drawbacks are that HSCs are rare ( 1 in 100,000 cells from BM) and pose major risks with graft rejection and graft-versus-host disease (GvHD). Subacute intraspinal transplantation of HSCs was shown to promote functional recovery after compression SCI in mice $(82,83)$. For clinical translation, HSCs are commonly harvested from peripheral blood following cytokine administration, which mobilizes the HSCs, and the MNC fraction is administered. 
Table 1

Summary of advantages and disadvantages of potential stem cell types for SCI

\begin{tabular}{|c|c|c|c|c|c|c|c|c|c|}
\hline & \multirow[t]{2}{*}{ ES cells } & \multicolumn{2}{|c|}{ NSPCs } & \multirow[t]{2}{*}{ SKPs } & \multirow[t]{2}{*}{ HSCs/BM-MNCs } & \multicolumn{2}{|c|}{ MSCs } & \multirow[t]{2}{*}{ iPSCs } & \multirow[t]{2}{*}{ iNPCs } \\
\hline & & Fetal & Adult & & & $\begin{array}{c}\text { BM- } \\
\text { derived }\end{array}$ & $\begin{array}{c}\text { Other } \\
\text { sources }\end{array}$ & & \\
\hline Availability & Yes & Yes & No & Yes & Yes & Yes & Yes & Yes & Yes \\
\hline Ease of isolation & No & No & No & Yes & Yes & Yes & Yes & No & Yes \\
\hline Autologous donors & No & No & No & Yes & Yes & Yes & Yes & Yes & Yes \\
\hline Ethical considerations & Yes & Yes & No & No & No & No & No & No & No \\
\hline $\begin{array}{l}\text { Differentiation } \\
\text { potential }\end{array}$ & Pluripotent & Neural & Neural & $\begin{array}{l}\text { Nonneural } \\
\text { and } \\
\text { peripheral } \\
\text { myelin only }\end{array}$ & $\begin{array}{l}\text { Nonneural } \\
\text { and } \\
\text { potentially } \\
\text { neural }\end{array}$ & $\begin{array}{l}\text { Nonneural } \\
\text { and } \\
\text { potentially } \\
\text { neural }\end{array}$ & & Pluripotent & Neural \\
\hline Tumorigenicity & Yes & Some & No & Unknown & No & No & Unknown & Yes & Unknown \\
\hline Pathotropism & Unknown & Yes & Yes & Unknown & Yes & Yes & Yes & Unknown & Unknown \\
\hline $\begin{array}{l}\text { Efficacy in preclinical } \\
\text { studies }\end{array}$ & $\begin{array}{l}\text { Yes, in some } \\
\text { studies }\end{array}$ & Inconsistent & $\begin{array}{l}\text { Yes, } \\
\text { in many }\end{array}$ & $\begin{array}{c}\text { Yes, } \\
\text { but few }\end{array}$ & $\begin{array}{c}\text { Yes, } \\
\text { in some }\end{array}$ & Inconsistent & $\begin{array}{l}\text { Yes, } \\
\text { in many }\end{array}$ & $\begin{array}{l}\text { Yes, for } \\
\text { preclones }\end{array}$ & Unknown \\
\hline $\begin{array}{l}\text { Safety in human } \\
\text { trials }\end{array}$ & $\begin{array}{l}\text { Yes, for ES } \\
\text { cell-derived } \\
\text { OPC Geron } \\
\text { trial }\end{array}$ & $\begin{array}{l}\text { Stem Cells } \\
\text { Inc. }\end{array}$ & Untested & Untested & Yes & Yes & Yes & Untested & Untested \\
\hline
\end{tabular}

The most common nonneural cell type for transplantation in experimental SCI is the BMSC. BMSCs are isolated from the MNC fraction of $\mathrm{BM}$ and expanded in culture based on their adherence to tissue culture plastic and expression of distinct cell-surface antigens that do not include HSC markers. The major advantage of MSCs is that they can be autologously transplanted and that they express a variety of neurotrophic factors that are beneficial for repair. Other important features are their low immunogenicity and their reported immunomodulatory properties (ref. 84 and Table 1). MSCs are widespread throughout a variety of tissues (85), including Wharton jelly of the umbilical cord, adipose tissue, adult muscle, and the dental pulp of deciduous baby teeth. Recently, predifferentiated adipose-derived MSCs were transplanted into SCI rats, resulting in some functional recovery, perhaps due to paracrine effects of grafted cells wrapping demyelinated host axons and promoting their protection (86). Umbilical cordderived HSCs or MSCs are attractive because this tissue is readily accessible and frequently discarded, and MSCs are less prone to rejection, as evidenced by a lower risk of developing GvHD (ref. 87 and Table 1). Compared with adult sources, the number of MSCs or HSCs obtained from cord blood or placental tissues is small, although they can be readily expanded and tissue can be frozen and used later for isolation (88).

Transplantation of BMSCs for SCI has been previously reviewed $(2,3,6,89,90)$. Many studies have examined BMSCs in SCI rodents, with some showing improved locomotor recovery (91-93), while others did not $(51,94,95)$, likely due to differences in culture conditions. Several studies have also shown MSC differentiation into neural lineages in vitro, although in vivo, this is controversial (88-90). Cumulative evidence suggests the therapeutic effects of MSCs are likely due to secretion of neurotrophins, angiogenesis, and antiinflammatory actions (60, 93, 96, 97). HSCs and MSCs have also shown variable efficacy when transplanted intravenously or intrathecally demonstrating pathotropism (98-100). Despite these potential benefits, there are reported adverse effects of MSCs, such as increased recurrence of hematological malignancies and enhanced tumor growth and metastases $(90,101,102)$.

There are number of completed and currently ongoing SCI clinical trials involving autologous BM-MNC or BMSC transplantation as summarized in Tables 2 and 3. There are other reports of small numbers of patients treated with MSC transplants showing no adverse effects $(103,104)$. Collectively, evidence suggests that even transient MSC engraftment may exert favorable effects through secretion of cytokines and other paracrine factors that engage and recruit recipient cells in tissue repair (105).

\section{iPSCs}

iPSCs are generated by reprogramming mature, fully differentiated cells into a pluripotent state. The advantage of iPSCs is that easily accessible cells such as skin from an SCI patient could be reprogrammed, differentiated, and transplanted. iPSCs were developed in 2006 by Takahashi and Yamanaka, who showed that mouse somatic cells, such as fibroblasts, could be reprogrammed to pluripotency with retroviral expression of the transcription factors OCT4, SOX2, KLF4, and c-MYC (106). iPSCs can also be generated from human somatic cells $(107,108)$. The ability to generate pluripotent cells from adult somatic cells without the need for an embryo was a major development in stem cell biology.

Puri and Nagy recently compared ES cells and iPSCs (109). iPSCs share many key properties with ES cells, including morphology, pluripotency, self renewal, and gene expression. During expansion and prolonged passage, human ES cell lines frequently acquire abnormal karyotypes and genetic amplification associated with oncogenic transformation, which is also the case with iPSC lines (109). One of the main problems with generation of iPSCs is the expression of reprogramming factors associated with teratoma formation (110). For this reason, several alternative delivery methods have been developed for reprogramming that do not require 

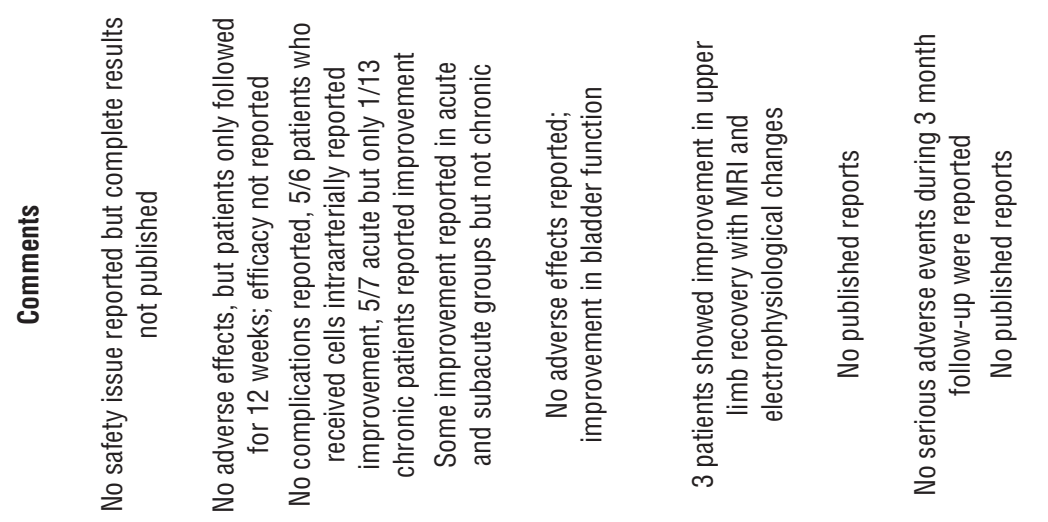

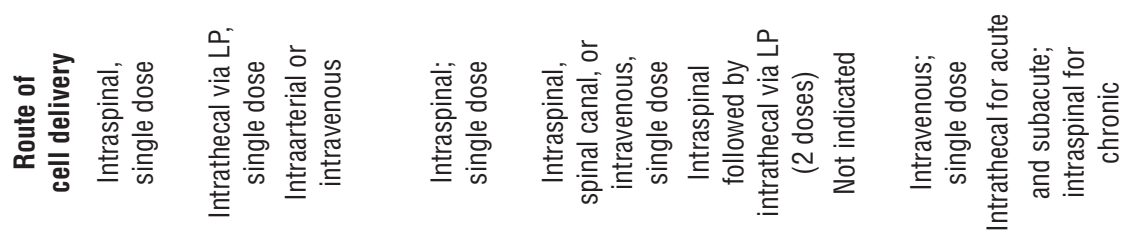

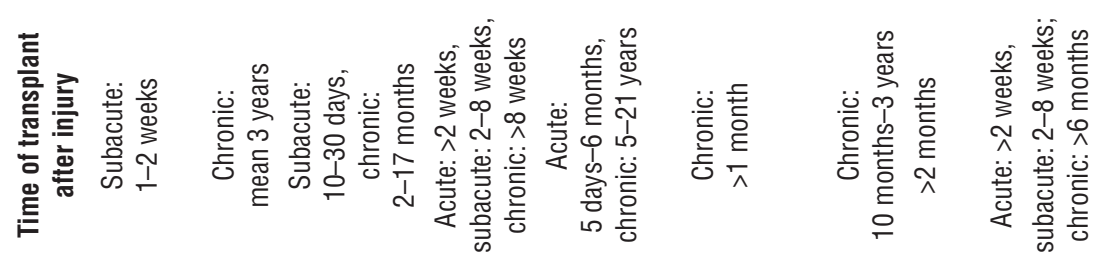

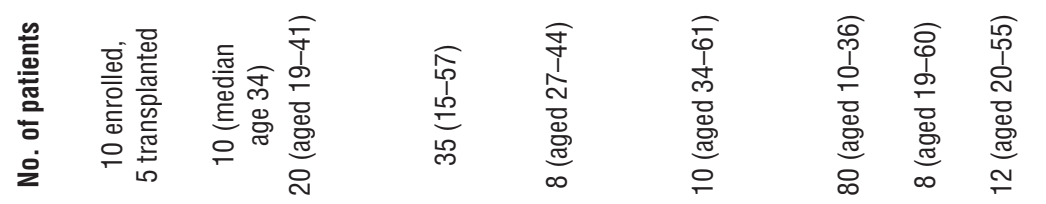

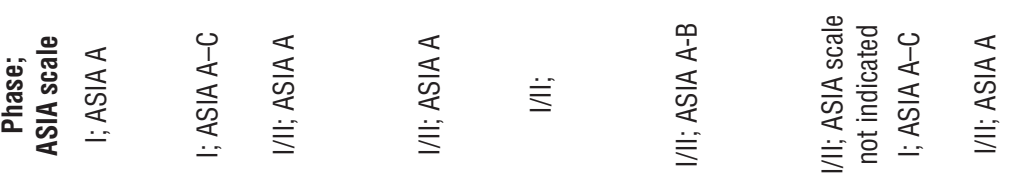

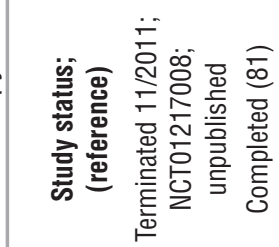

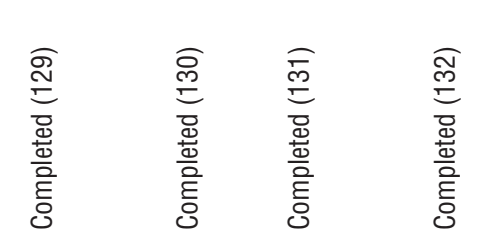

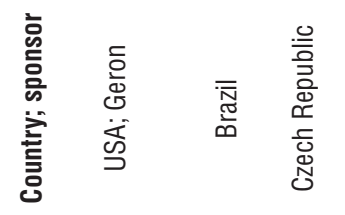

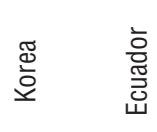

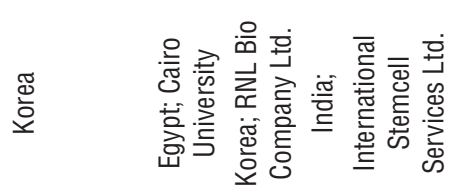

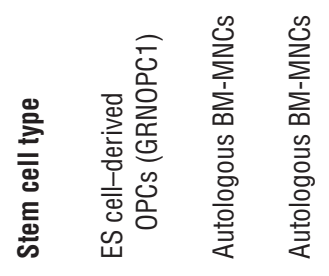

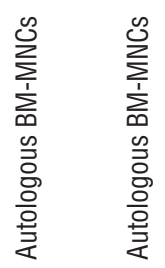

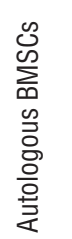
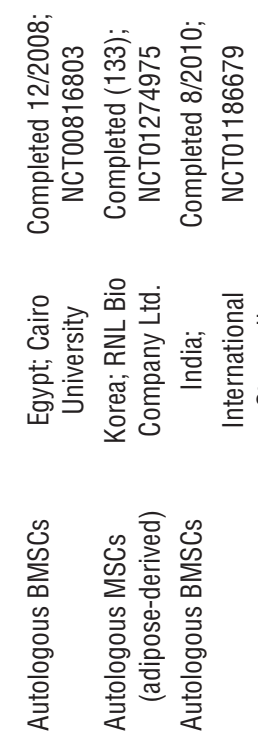

o 0 ठ ठ 


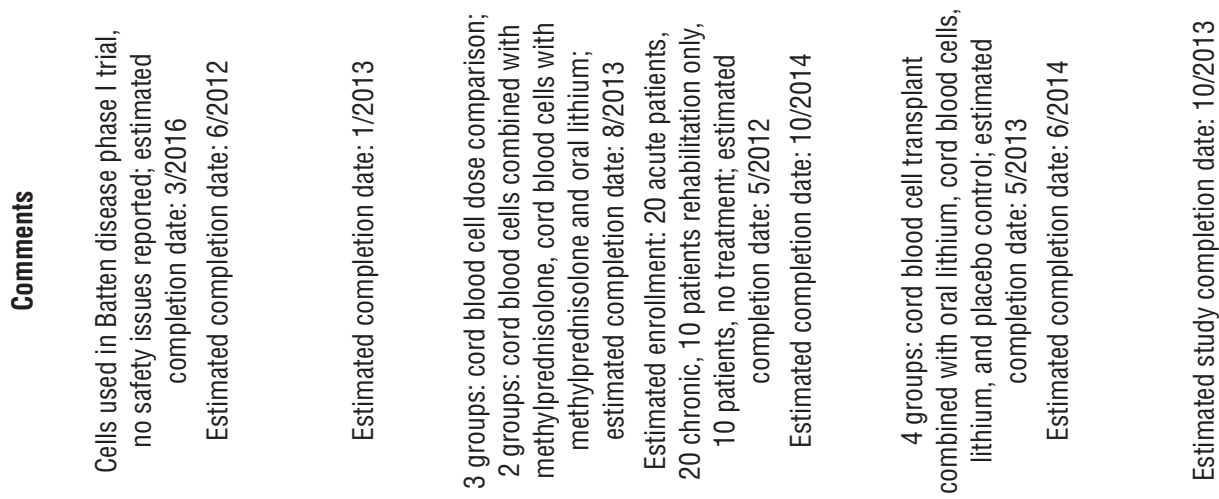

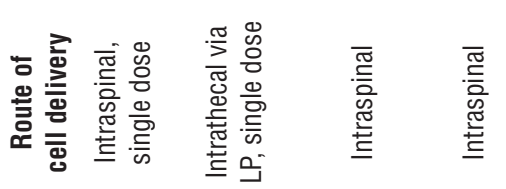
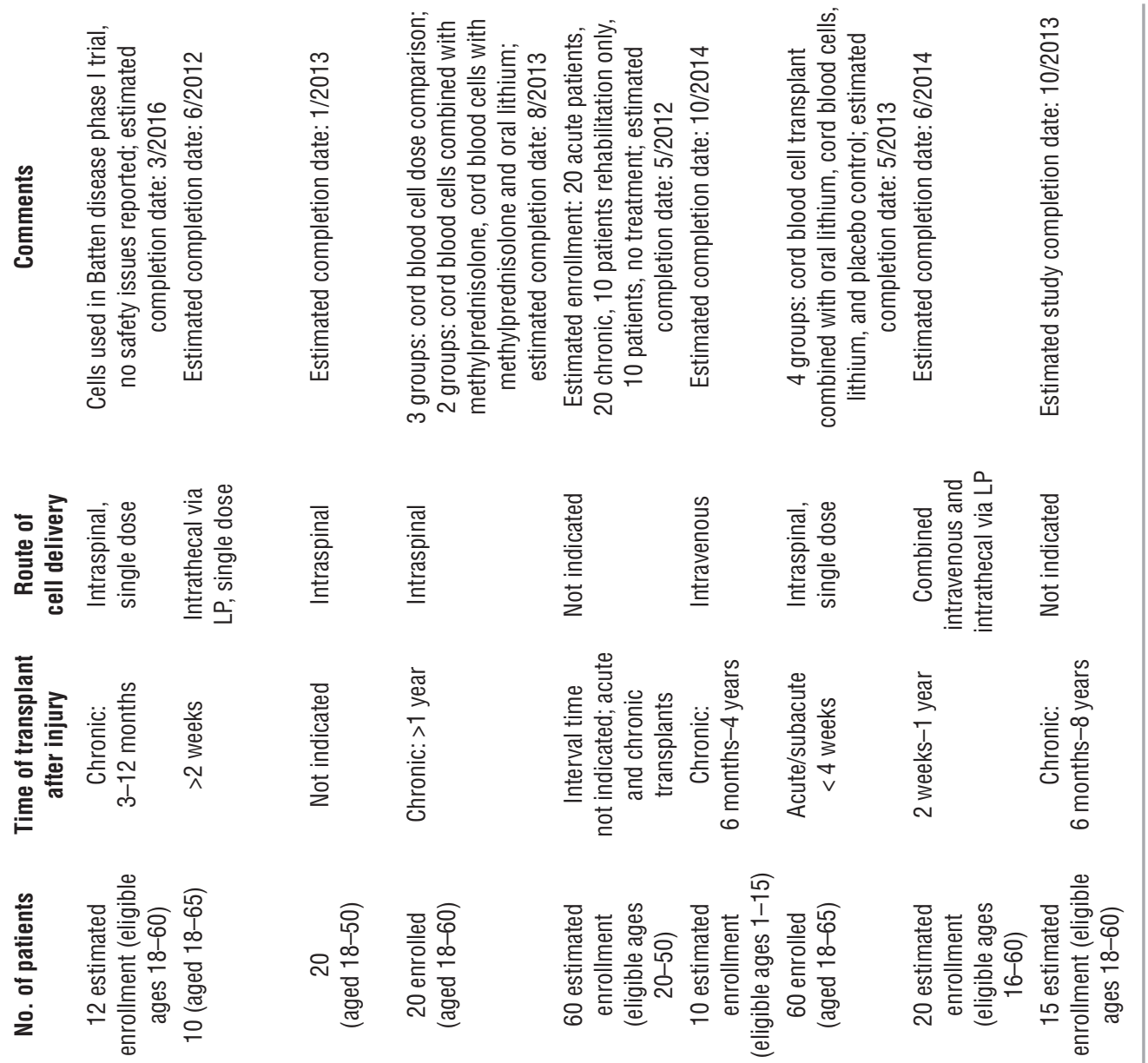

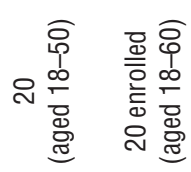
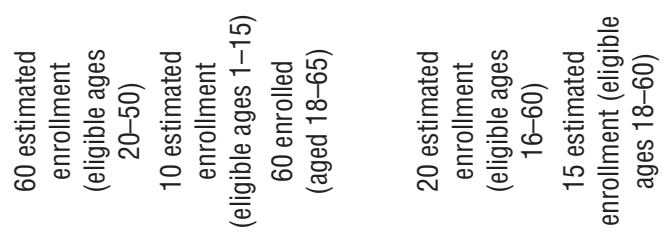

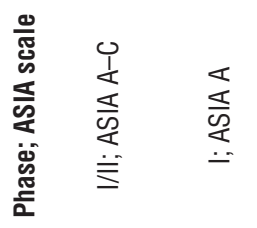

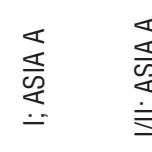

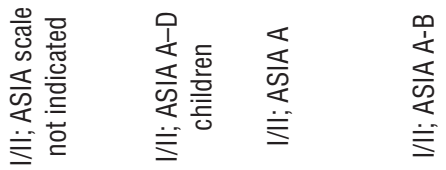

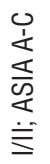

ভ

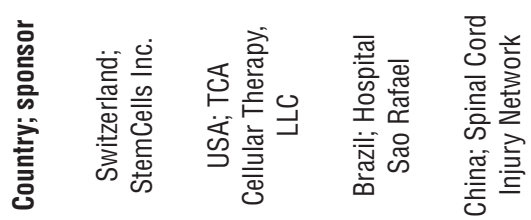

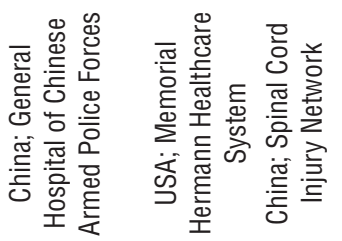

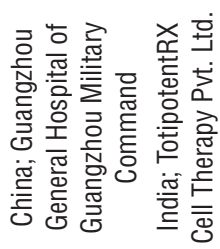

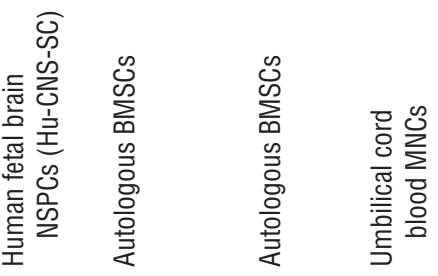

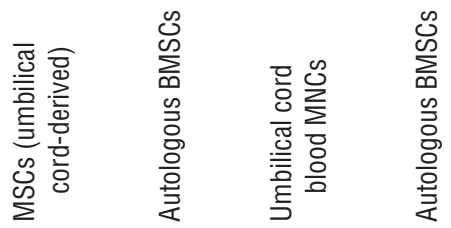


permanent transgene integrations, such as adenovirus, the piggyBac transposon, and direct protein transduction $(109,111)$. These reprogramming factors are needed to initiate but not sustain somatic cell transformation into iPSCs, which is very important from a therapeutic standpoint. However, for clinical translation, the development of reproducible protocols for iPSC differentiation to specific neural lineages with complete elimination of residual pluripotent stem cells is necessary.

Recently, it was demonstrated that NSPCs can be derived from human iPSCs, but human iPSC differentiation to neural lineages occurs at a much lower frequency than with ES cells (112). Also, some types of iPSC-derived neural cells have an increased likelihood of tumor formation after transplantation into the CNS. Thus, safe iPSC-derived clones will need to be screened and selected $(113,114)$. Experimental studies using preselected "safe" iPSC-derived neurospheres transplanted subacutely after contusion SCI showed remyelination, axonal outgrowth of serotonergic fibers, and promotion of locomotor recovery (114). In contrast, transplantation of "unsafe" iPS-derived neurospheres resulted in robust teratoma formation and sudden loss of locomotor function (114). Transplantation of murine iPSC-derived astrocytes into SCI rats resulted in allodynia (115). Recently, Okano and colleagues grafted human iPSC-derived neurospheres into the injured mouse spinal cord and demonstrated improved locomotor recovery with synapse formation between host and grafted cells, expression of neurotrophic factors, angiogenesis, axonal regrowth, and increased myelination (116). No tumor formation occurred in the grafted mice with the preselected clones. Also, a recent study showed that transplanted human iPSC-derived self-renewing neuroepithelial-like stem cells differentiated into neuronal progeny in the injured mouse spinal cord and restored synaptic connections, contributing to improved motor function (117).

\section{Direct conversion to neural cells}

Recently, direct conversion of a cell into a different cell type bypassing the pluripotent stage was shown. For example, hematopoietic cells were generated directly from human dermal fibroblasts without establishing pluripotency via the ectopic expression of hematopoietic transcription factors (118), and mouse embryonic fibroblasts were directly reprogrammed to cardiomyocytes (119). Several studies demonstrated direct conversion of mouse and human skin or liver cells into neurons (termed induced neuronal cells) with the combinatorial expression of neural lineage-specific transcription factors (120-122). The reprogramming factors appear to lead to a switch in lineage fate rather than an induction of hybrid phenotypes, although the induced neuronal cells retain a small but detectable epigenetic memory of their donor cells (120). The interconversion between adult cells from ontogenically different lineages by an induced transdifferentiation process without the need for establishing pluripotency provides a novel tool for adult cell fate modification (123).

Wernig and colleagues showed recently that mouse embryonic fibroblasts can be directly converted to self-renewing neural precursor cells that generate both neurons and glia and can be expanded in large numbers (124). The next step will be to determine whether similar induced neural precursor cells (iNPCs) can be generated from adult human fibroblasts and whether these are safe. These new developments in stem cell biology suggest that pluripotency is no longer a prerequisite for somatic cell repro- gramming. This alternative approach to cellular reprogramming for autologous cell replacement therapies avoids complications associated with the use of human pluripotent stem cells (118), such as tumorigenicity. However, more work needs to be done to elucidate the process of direct conversion.

\section{Summary of challenges for clinical translation of stem cell therapy for $\mathrm{SCI}$}

Clinical translation of stem cell therapy for SCI still faces enormous challenges, although much has been learned from previous SCI and other trials. However, most have been phase I trials conducted with small numbers of patients without controls, and thus, assessment of efficacy is not possible (1). Enrolling sufficient numbers of SCI patients for clinical trials has been difficult because of differing severity and level of injury, age of patient, and associated injuries. Generally, for cell transplantation trials, the target SCI population has been ASIA A patients to avoid causing further damage, but these patients may have minimal ability to recover, and demonstration of effectiveness is impaired due to insensitive outcome measures. For example, short-length axonal regeneration would be undetected in thoracic injuries. Some of the obstacles the Geron trial encountered were the need to screen large numbers of patients, the need to inject a large number of cells ( 2 million per patient), and a relatively long wait time to ascertain clinical efficacy (more than six months). The process of creating clinically acceptable ES cellderived cells is costly, and the same challenges apply to iPSCderived cells. Recent developments with direct conversion methods indicate great potential for clinical stem cell therapy, but more work is needed. In contrast, there are 50 years of research in the adult stem cell field with HSCs, which are routinely used to treat patients with leukemia and related bone/blood cancers. Many clinical case reports describing MSC therapy for stroke, multiple sclerosis, and in orthopedic conditions have been published (125-128). Given the large amount of preclinical data and the safety record, it is understandable that so many clinical trials have used MSC-based therapies. However, answers will not come from small, uncoordinated phase I trials. Also, for reasons outlined in consensus panels, it is important for patients to avoid experimental therapy outside of a formal, clinical trial. The complexities of attenuating the tissue damage and secondary complications due to trauma and reconstructing the cytoarchitecture of the injured spinal cord are very challenging, but hopefully, the rapid advances being made in stem cell biology will result in effective experimental and clinical trials of stem cell therapy for SCI.

\section{Acknowledgments}

We thank the Canadian Paraplegic Association (Ontario branch), the Christopher and Dana Reeve Foundation, Physicians' Services Incorporated, the Ontario Neurotrauma Foundation, and Krembil Foundation SCI-NET (new emerging team) for a grant for financial support. We also thank the reviewers for their helpful suggestions and the editors of JCI.

Address correspondence to: Charles H. Tator, Toronto Western Research Institute and Krembil Neuroscience Centre, Toronto Western Hospital, 399 Bathurst Street, Toronto, ON, Canada M5T 2S8. Phone: 416.603.5889; Fax: 416.603.5745; E-mail: charles. tator@uhn.on.ca. 
1. Tator CH. Review of treatment trials in human spinal cord injury: issues, difficulties, and recommendations. Neurosurgery. 2006;59(5):957-982.

2. Fehlings MG, Vawda R. Cellular treatments for spinal cord injury: the time is right for clinical trials. Neurotherapeutics. 2011;8(4):704-720.

3. Tetzlaff W, et al. A systematic review of cellular transplantation therapies for spinal cord injury. J Neurotrauma. 2011;28(8):1611-1682.

4. Sahni V, Kessler JA. Stem cell therapies for spinal cord injury. Nat Rev Neurol. 2010;6(7):363-372.

5. Thomas KE, Moon LD. Will stem cell therapies be safe and effective for treating spinal cord injuries? Br Med Bull. 2011;98:127-142.

6. Wright KT, El Masri W, Osman A, Chowdhury J, Johnson WE. Bone marrow for the treatment of spinal cord injury: mechanisms and clinical application. Stem Cells. 2011;29(2):169-178.

7. Enzmann GU, Benton RL, Talbott JF, Cao Q, Whittemore SR. Functional considerations of stem cell transplantation therapy for spinal cord repair. J Neurotrauma. 2006;23(3-4):479-495.

8. Thuret S, Moon LD, Gage FH. Therapeutic interventions after spinal cord injury. Nat Rev Neurosci. 2006; 7(8):628-643.

9. Ackery A, Tator C, Krassioukov A. A global perspective on spinal cord injury epidemiology. J Neu rotrauma. 2004;21(10):1355-1370.

10. Farry A, Baxter D. The Incidence and Prevalence of Spinal Cord Injury in Canada: Overview and estimates based on current evidence. Vancouver, British Columbia, Canada: Rick Hansen Institute; 2010.

11. [No authors listed]. One Degree of Separation: Paralysis and SCI in the United States. Short Hills, New Jersey, USA: Christopher and Dana Reeve Foundation; 2009.

12. Tator $\mathrm{CH}$. Epidemiology and general characteristics of the spinal cord injury patient. In: Benzel EC, ed. Contemporary Management Of Spinal Cord Injury. Park Ridge, Illinois, USA: American Association of Neurological Surgeons; 1995:9-13.

13. Wyndaele M, Wyndaele JJ. Incidence, prevalence and epidemiology of spinal cord injury: what learns a worldwide literature survey? Spinal Cord. 2006; 44(9):523-529.

14. Fehlings MG, Sekhon LH. Acute interventions in spinal cord injury: what do we know, what should we do? Clin Neurosurg. 2001;48:226-242.

15. Bracken MB, et al. Administration of methylprednisolone for 24 or 48 hours or tirilazad mesylate for 48 hours in the treatment of acute spinal cord injury. Results of the Third National Acute Spinal Cord Injury Randomized Controlled Trial. National Acute Spinal Cord Injury Study. JAMA. 1997; 277(20):1597-1604.

16. Braughler JM, Hall ED, Means ED, Waters TR, Anderson DK. Evaluation of an intensive methylprednisolone sodium succinate dosing regimen in experimental spinal cord injury. J Neurosurg. 1987; 67(1):102-105.

17. Hurlbert RJ, Hamilton MG. Methylprednisolone for acute spinal cord injury: 5-year practice reversal. Can J Neurol Sci. 2008;35(1):41-45.

18. Kwon BK, et al. A systematic review of non-invasive pharmacologic neuroprotective treatments for acute spinal cord injury. J Neurotrauma. 2011; 28(8):1545-1588

19. Hulsebosch CE. Recent advances in pathophysiology and treatment of spinal cord injury. Adv Physiol Educ. 2002;26(1-4):238-255.

20. Tator CH. Update on the pathophysiology and pathology of acute spinal cord injury. Brain Pathol. 1995;5(4):407-413

21. Tator CH, Fehlings MG. Review of the secondary injury theory of acute spinal cord trauma with emphasis on vascular mechanisms. J Neurosurg. 1991;75(1):15-26.

22. Fawcett JW, Asher RA. The glial scar and central nervous system repair. Brain Res Bull. 1999;
49(6):377-391.

23. Tator C, Poon P. Acute clip impact-compression model. In: Chen J, Xu ZC, Xiao-Ming X, Zhang JH, eds. Animal Models of Acute Neurological Injuries. New York, New York, USA: Humana Press; 2009:449-460.

24. Richardson PM, McGuinness UM, Aguayo AJ. Axons from CNS neurons regenerate into PNS grafts. Nature. 1980;284(5753):264-265.

25. Bregman BS, Reier PJ. Neural tissue transplants rescue axotomized rubrospinal cells from retrograde death. J Comp Neurol. 1986;244(1):86-95.

26. Evans MJ, Kaufman MH. Establishment in culture of pluripotential cells from mouse embryos. Nature. 1981;292(5819):154-156.

27. Zhang SC, Wernig M, Duncan ID, Brustle O, Thomson JA. In vitro differentiation of transplantable neural precursors from human embryonic stem cells. Nat Biotechnol. 2001;19(12):1129-1133.

28. Tropepe V, Hitoshi S, Sirard C, Mak TW, Rossant J, van der Kooy D. Direct neural fate specification from embryonic stem cells: a primitive mammalian neural stem cell stage acquired through a default mechanism. Neuron. 2001;30(1):65-78.

29. Reubinoff BE, et al. Neural progenitors from human embryonic stem cells. Nat Biotechnol. 2001; 19(12):1134-1140.

30. Carpenter MK, Inokuma MS, Denham J, Mujtaba T, Chiu CP, Rao MS. Enrichment of neurons and neural precursors from human embryonic stem cells. Exp Neurol. 2001;172(2):383-397.

31. Wichterle H, Lieberam I, Porter JA, Jessell TM. Directed differentiation of embryonic stem cells into motor neurons. Cell. 2002;110(3):385-397.

32. Wada $T$, et al. Highly efficient differentiation and enrichment of spinal motor neurons derived from human and monkey embryonic stem cells. PLoS One. 2009;4(8):e6722.

33. Brustle O, et al. Embryonic stem cell-derived glial precursors: a source of myelinating transplants. Science. 1999;285(5428):754-756.

34. Nistor GI, Totoiu MO, Haque N, Carpenter MK, Keirstead HS. Human embryonic stem cells differentiate into oligodendrocytes in high purity and myelinate after spinal cord transplantation. Glia. 2005;49(3):385-396.

35. McDonald JW, et al. Transplanted embryonic stem cells survive, differentiate and promote recovery in injured rat spinal cord. Nat Med. 1999; 5(12):1410-1412

36. Keirstead HS, et al. Human embryonic stem cellderived oligodendrocyte progenitor cell transplants remyelinate and restore locomotion after spinal cord injury. J Neurosci. 2005;25(19):4694-4705.

37. Sharp J, Frame J, Siegenthaler M, Nistor G, Keirstead HS. Human embryonic stem cell-derived oligodendrocyte progenitor cell transplants improve recovery after cervical spinal cord injury. Stem Cells. 2010;28(1):152-163.

38. Gage FH. Mammalian neural stem cells. Science. 2000;287(5457):1433-1438.

39. Reynolds BA, Weiss S. Generation of neurons and astrocytes from isolated cells of the adult mammalian central nervous system. Science. 1992; 255(5052):1707-1710.

40. Morshead CM, et al. Neural stem cells in the adult mammalian forebrain: a relatively quiescent subpopulation of subependymal cells. Neuron. 1994; 13(5):1071-1082.

41. Gritti A, et al. Multipotential stem cells from the adult mouse brain proliferate and self-renew in response to basic fibroblast growth factor. J Neurosci. 1996;16(3):1091-1100.

42. Palmer TD, Takahashi J, Gage FH. The adult rat hippocampus contains primordial neural stem cells. Mol Cell Neurosci. 1997;8(6):389-404.

43. Weiss S, et al. Multipotent CNS stem cells are present in the adult mammalian spinal cord and ventricular neuroaxis. J Neurosci. 1996;16(23):7599-7609.
44. Kulbatski I, Mothe AJ, Keating A, Hakamata Y, Kobayashi E, Tator CH. Oligodendrocytes and radial glia derived from adult rat spinal cord progenitors: morphological and immunocytochemical characterization. J Histochem Cytochem. 2007; 55(3):209-222.

45. Martens DJ, Seaberg RM, van der Kooy D. In vivo infusions of exogenous growth factors into the fourth ventricle of the adult mouse brain increase the proliferation of neural progenitors around the fourth ventricle and the central canal of the spinal cord. Eur J Neurosci. 2002;16(6):1045-1057.

46. Kulbatski I, Mothe AJ, Keating A, Hakamata Y, Kobayashi E, Tator CH. Oligodendrocytes and radial glia derived from adult rat spinal cord progenitors: morphological and immunocytochemical characterization. J Histochem Cytochem. 2007; 55(3):209-222.

47. Mothe AJ, Tator CH. Transplanted neural stem/ progenitor cells generate myelinating oligodendrocytes and Schwann cells in spinal cord demyelination and dysmyelination. Exp Neurol. 2008; 213(1):176-190.

48. Mothe AJ, Kulbatski I, Parr A, Mohareb M, Tator $\mathrm{CH}$. Adult spinal cord stem/progenitor cells transplanted as neurospheres preferentially differentiate into oligodendrocytes in the adult rat spinal cord. Cell Transplant. 2008;17(7):735-751.

49. Hofstetter CP, et al. Allodynia limits the usefulness of intraspinal neural stem cell grafts; directed differentiation improves outcome. Nat Neurosci. 2005; $8(3): 346-353$

50. Moreno-Manzano V, et al. Activated spinal cord ependymal stem cells rescue neurological function. Stem Cells. 2009;27(3):733-743.

51. Parr AM, et al. Transplanted adult spinal cordderived neural stem/progenitor cells promote early functional recovery after rat spinal cord injury. Neuroscience. 2008;155(3):760-770.

52. Karimi-Abdolrezaee S, Eftekharpour E, Wang J, Morshead CM, Fehlings MG. Delayed transplantation of adult neural precursor cells promotes remyelination and functional neurological recovery after spinal cord injury. J Neurosci. 2006; 26(13):3377-3389.

53. Karimi-Abdolrezaee S, Eftekharpour E, Wang J, Schut D, Fehlings MG. Synergistic effects of transplanted adult neural stem/progenitor cells, chondroitinase, and growth factors promote functional repair and plasticity of the chronically injured spinal cord. J Neurosci. 2010;30(5):1657-1676.

54. Ogawa Y, et al. Transplantation of in vitro-expanded fetal neural progenitor cells results in neurogenesis and functional recovery after spinal cord contusion injury in adult rats. J Neurosci Res. 2002; 69(6):925-933.

55. Abematsu M, et al. Neurons derived from transplanted neural stem cells restore disrupted neuronal circuitry in a mouse model of spinal cord injury. J Clin Invest. 2010;120(9):3255-3266.

56. Ziv Y, Avidan H, Pluchino S, Martino G, Schwartz M. Synergy between immune cells and adult neural stem/progenitor cells promotes functional recovery from spinal cord injury. Proc Natl Acad Sci US A. 2006;103(35):13174-13179.

57. Ferrari D, et al. Differential pathotropism of nonimmortalized and immortalized human neural stem cell lines in a focal demyelination model. Cell Mol Life Sci. 2012;69(7):1193-1210.

58. Yan J, Welsh AM, Bora SH, Snyder EY, Koliatsos VE. Differentiation and tropic/trophic effects of exogenous neural precursors in the adult spinal cord. J Comp Neurol. 2004;480(1):101-114.

59. Lu P, Jones LL, Snyder EY, Tuszynski MH. Neural stem cells constitutively secrete neurotrophic factors and promote extensive host axonal growth after spinal cord injury. Exp Neurol. 2003; 181(2):115-129. 
60. Hawryluk GW, Mothe AJ, Chamankhah M, Wang J, Tator C, Fehlings MG. In vitro characterization of trophic factor expression in neural precursor cells. Stem Cells Dev. 2012;21(3):432-447.

61. Carpenter MK, et al. In vitro expansion of a multipotent population of human neural progenitor cells. Exp Neurol. 1999;158(2):265-278.

62. Ostenfeld T, et al. Regional specification of rodent and human neurospheres. Brain Res Dev Brain Res. 2002;134(1-2):43-55

63. Piao JH, et al. Cellular composition of long-term human spinal cord- and forebrain-derived neurosphere cultures. J Neurosci Res. 2006;84(3):471-482.

64. Svendsen CN, et al. A new method for the rapid and long term growth of human neural precursor cells. J Neurosci Methods. 1998;85(2):141-152.

65. Vescovi AL, et al. Isolation and cloning of multipotential stem cells from the embryonic human CNS and establishment of transplantable human neural stem cell lines by epigenetic stimulation. Exp Neurol. 1999;156(1):71-83.

66. Kukekov VG, et al. Multipotent stem/progenitor cells with similar properties arise from two neurogenic regions of adult human brain. Exp Neurol. 1999;156(2):333-344.

67. Palmer TD, Schwartz PH, Taupin P, Kaspar B, Stein SA, Gage FH. Cell culture. Progenitor cells from human brain after death. Nature. 2001;411:42-43.

68. Nunes MC, Roy NS, Keyoung HM, Goodman RR, McKhann G. Identification and isolation of multipotential neural progenitor cells from the subcortical white matter of the adult human brain. Nat Med. 2003;9(4):439-447.

69. Schwartz PH, Bryant PJ, Fuja TJ, Su H, O’Dowd DK, Klassen H. Isolation and characterization of neural progenitor cells from post-mortem human cortex. J Neurosci Res. 2003;74(6):838-851.

70. Mothe AJ, Zahir T, Santaguida C, Cook D, Tator $\mathrm{CH}$. Neural stem/progenitor cells from the adult human spinal cord are multipotent and self-renewing and differentiate after transplantation. PLOS One. 2011;6(11):e27079.

71. Cummings BJ, et al. Human neural stem cells differentiate and promote locomotor recovery in spinal cord-injured mice. Proc Natl Acad Sci US A. 2005; 102(39):14069-14074.

72. Salazar DL, Uchida N, Hamers FP, Cummings BJ, Anderson AJ. Human neural stem cells differentiate and promote locomotor recovery in an early chronic spinal cord injury NOD-scid mouse model. PLoS One. 2010;5(8):e12272.

73. Yan J, et al. Extensive neuronal differentiation of human neural stem cell grafts in adult rat spinal cord. PLoS Med. 2007;4(2):e39.

74. Yamane J, et al. Transplantation of galectin-1-expressing human neural stem cells into the injured spinal cord of adult common marmosets. J Neurosci Res. 2010;88(7):1394-1405.

75. Hu YF, Gourab K, Wells C, Clewes O, Schmit BD, Sieber-Blum M. Epidermal neural crest stem cell (EPI-NCSC)-mediated recovery of sensory function in a mouse model of spinal cord injury. Stem Cell Rev. 2010;6(2):186-198.

76. Joannides A, et al. Efficient generation of neural precursors from adult human skin: astrocytes promote neurogenesis from skin-derived stem cells. Lancet. 2004;364(9429):172-178.

77. Toma JG, et al. Isolation of multipotent adult stem cells from the dermis of mammalian skin. Nat Cell Biol. 2001;3(9):778-784.

78. Fernandes KJ, et al. Analysis of the neurogenic potential of multipotent skin-derived precursors. Exp Neurol. 2006;201(1):32-48.

79. Biernaskie J, et al. Skin-derived precursors generate myelinating Schwann cells that promote remyelination and functional recovery after contusion spinal cord injury. J Neurosci. 2007;27(36):9545-9559.

80. Becker AJ, McCulloch CE, Till JE. Cytological dem- onstration of the clonal nature of spleen colonies derived from transplanted mouse marrow cells. Nature. 1963;197:452-454.

81. Callera F, do Nascimento RX. Delivery of autologous bone marrow precursor cells into the spinal cord via lumbar puncture technique in patients with spinal cord injury: a preliminary safety study. Exp Hematol. 2006;34(2):130-131.

82. Koshizuka S, et al. Transplanted hematopoietic stem cells from bone marrow differentiate into neural lineage cells and promote functional recovery after spinal cord injury in mice. J Neuropathol Exp Neurol. 2004;63(1):64-72.

83. Koda M, et al. Hematopoietic stem cell and marrow stromal cell for spinal cord injury in mice. Neuroreport. 2005;16(16):1763-1767.

84. Keating A. Mesenchymal stromal cells. Curr Opin Hematol. 2006;13(6):419-425.

85 . Young HE, et al. Mesenchymal stem cells reside within the connective tissues of many organs. Dev Dyn. 1995;202(2):137-144.

86. Arboleda D, et al. Transplantation of predifferentiated adipose-derived stromal cells for the treatment of spinal cord injury. Cell Mol Neurobiol. 2011; 31(7):1113-1122.

87. Laughlin MJ, et al. Hematopoietic engraftment and survival in adult recipients of umbilical-cord blood from unrelated donors. N Engl J Med. 2001; 344(24):1815-1822

88. Park DH, Lee JH, Borlongan CV, Sanberg PR, Chung YG, Cho TH. Transplantation of umbilical cord blood stem cells for treating spinal cord injury. Stem Cell Rev. 2011;7(1):181-194.

89. Parr AM, Tator CH, Keating A. Bone marrowderived mesenchymal stromal cells for the repair of central nervous system injury. Bone Marrow Transplant. 2007;40(7):609-619.

90. Wong RSY. Mesenchymal stem cells: angels or demons? J Biomed Biotechnol. 2011(2011):459510.

91. Chopp M, et al. Spinal cord injury in rat: treatment with bone marrow stromal cell transplantation. Neuroreport. 2000;11(13):3001-3005.

92. Hofstetter CP, et al. Marrow stromal cells form guiding strands in the injured spinal cord and promote recovery. Proc Natl Acad Sci U S A. 2002; 99(4):2199-2204.

93. Himes BT, et al. Recovery of function following grafting of human bone marrow-derived stromal cells into the injured spinal cord. Neurorehabil Newral Repair. 2006;20(2):278-296.

94. Ankeny DP, McTigue DM, Jakeman LB. Bone marrow transplants provide tissue protection and directional guidance for axons after contusive spinal cord injury in rats. Exp Neurol. 2004;190(1):17-31.

95. Lu P, Jones LL, Tuszynski MH. BDNF-expressing marrow stromal cells support extensive axonal growth at sites of spinal cord injury. Exp Neurol. 2005;191(2):344-360.

96. Hawryluk GW, Mothe A, Wang J, Wang S, Tator C, Fehlings MG. An in vivo characterization of trophic factor production following neural precursor cell or bone marrow stromal cell transplantation for spinal cord injury. Stem Cells Dev. 2012; 21(12):2222-2238.

97. Caplan AI, Dennis JE. Mesenchymal stem cells as trophic mediators.J Cell Biochem. 2006;98(5):1076-1084.

98. Bakshi A, Hunter C, Swanger S, Lepore A, Fischer I. Minimally invasive delivery of stem cells for spinal cord injury: advantages of the lumbar puncture technique. J Neurosurg Spine. 2004;1(3):330-337.

99. Osaka M, et al. Intravenous administration of mesenchymal stem cells derived from bone marrow after contusive spinal cord injury improves functional outcome. Brain Res. 2010;1343:226-235.

100.Paul C, Samdani AF, Betz RR, Fischer I, Neuhuber B. Grafting of human bone marrow stromal cells into spinal cord injury: a comparison of delivery methods. Spine. 2009;34(4):328-334.
101.Ramasamy R, Lam EW, Soeiro I, Tisato V, Bonnet D, Dazzi F. Mesenchymal stem cells inhibit proliferation and apoptosis of tumor cells: impact on in vivo tumor growth. Lenkemia. 2007;21(2):304-310.

102. Wang X, Zhang Z, Yao C. Survivin is upregulated in myeloma cell lines cocultured with mesenchymal stem cells. Leuk Res. 2010;34(10):1325-1329.

103.Attar A, et al. An attempt to treat patients who have injured spinal cords with intralesional implantation of concentrated autologous bone marrow cells. Cytotherapy. 2011;13(1):54-60.

104.Kumar AA, Kumar SR, Narayanan R, Arul K, Baskaran M. Autologous bone marrow derived mononuclear cell therapy for spinal cord injury: A phase I/II clinical safety and primary efficacy data. Exp Clin Transplant. 2009;7(4):241-248.

105. Tolar J, Le Blanc K, Keating A, Blazar BR. Concise review: hitting the right spot with mesenchymal stromal cells. Stem Cells. 2010;28(8):1446-1455.

106. Takahashi K, Yamanaka S. Induction of pluripotent stem cells from mouse embryonic and adult fibroblast cultures by defined factors. Cell. 2006; 126(4):663-676.

107. Park IH, et al. Reprogramming of human somatic cells to pluripotency with defined factors. Nature. 2008;451(7175):141-146.

108. Takahashi K, et al. Induction of pluripotent stem cells from adult human fibroblasts by defined factors. Cell. 2007;131(5):861-872.

109.Puri MC, Nagy A. Concise review: Embryonic stem cells versus induced pluripotent stem cells: the game is on. Stem Cells. 2012;30(1):10-14.

110.Ben-David U, Benvenisty N. The tumorigenicity of human embryonic and induced pluripotent stem cells. Nat Rev Cancer. 2011;11(4):268-277.

111.Gonzalez F, Boue S, Izpisua Belmonte JC. Methods for making induced pluripotent stem cells: reprogramming à la carte. Nat Rev Genet. 2011; 12(4):231-242.

112.Hu BY, et al. Neural differentiation of human induced pluripotent stem cells follows developmental principles but with variable potency. Proc Natl Acad Sci U S A. 2010;107(9):4335-4340.

113. Miura K, et al. Variation in the safety of induced pluripotent stem cell lines. Nat Biotechnol. 2009; 27(8):743-745.

114. Tsuji O, et al. Therapeutic potential of appropriately evaluated safe-induced pluripotent stem cells for spinal cord injury. Proc Natl Acad Sci U S A. 2010;107(28):12704-12709.

115.Hayashi K, et al. Increase of sensitivity to mechanical stimulus after transplantation of murine induced pluripotent stem cell-derived astrocytes in a rat spinal cord injury model. J Neurosurg Spine. 2011;15(6):582-593.

116.Nori S, et al. Grafted human-induced pluripotent stem-cell-derived neurospheres promote motor functional recovery after spinal cord injury in mice. Proc Natl Acad Sci US A. 2011;108(40):16825-16830.

117. Fujimoto $Y$, et al. Treatment of a mouse model of spinal cord injury by transplantation of human induced pluripotent stem cell-derived long-term self-renewing neuroepithelial-like stem cells. Stem Cells. 2012;30(6):1163-1173.

118.Szabo E, et al. Direct conversion of human fibroblasts to multilineage blood progenitors. Nature. 2010;468(7323):521-526.

119.Efe JA, et al. Conversion of mouse fibroblasts into cardiomyocytes using a direct reprogramming strategy. Nat Cell Biol. 2011;13(3):215-222.

120. Marro S, et al. Direct lineage conversion of terminally differentiated hepatocytes to functional neurons. Cell Stem Cell. 2011;9(4):374-382.

121. Son EY, et al. Conversion of mouse and human fibroblasts into functional spinal motor neurons. Cell Stem Cell. 2011;9(3):205-218.

122.Vierbuchen T, Ostermeier A, Pang ZP, Kokubu Y, Südhof TC, Wernig M. Direct conversion of fibro- 
blasts to functional neurons by defined factors. Nature. 2010;463(7284):1035-1041.

123. Masip M, Veiga A, Izpisúa Belmonte JC, Simón C. Reprogramming with defined factors: from induced pluripotency to induced transdifferentiation. Mol Hum Reprod. 2010;16(11):856-868.

124.Lujan E, Chanda S, Ahlenius H, SüdhofTC, Wernig M. Direct conversion of mouse fibroblasts to selfrenewing, tripotent neural precursor cells. Proc Natl Acad Sci U S A. 2012;109(7):2527-2532.

125. Borlongan CV, Glover LE, Tajiri N, Kaneko Y, Freeman TB. The great migration of bone marrowderived stem cells toward the ischemic brain: therapeutic implications for stroke and other neurological disorders. Prog Neurobiol. 2011;95(2):213-228.

126.Connick P, et al. Autologous mesenchymal stem cells for the treatment of secondary progressive multiple sclerosis: an open-label phase 2a proof-ofconcept study. Lancet Neurol. 2012;11(2):150-156.

127. Gomez-Barrena E, et al. Bone regeneration: stem cell therapies and clinical studies in orthopaedics and traumatology.J Cell Mol Med. 2011;15(6):1266-1286.

128. Uccelli A, Laroni A, Freedman MS. Mesenchymal stem cells for the treatment of multiple sclerosis and other neurological diseases. Lancet Neurol. 2011; 10(7):649-656.

129. Sykova E, et al. Autologous bone marrow transplantation in patients with subacute and chronic spinal cord injury. Cell Transplant. 2006;15(8-9):675-687.

130. Yoon SH, et al. Complete spinal cord injury treatment using autologous bone marrow cell transplantation and bone marrow stimulation with granulocyte macrophage-colony stimulating factor: Phase I/II clinical trial. Stem Cells. 2007; 25(8):2066-2073

131.Geffner LF, et al. Administration of autologous bone marrow stem cells into spinal cord injury patients via multiple routes is safe and improves their quality of life: comprehensive case studies. Cell Transplant. 2008;17(12):1277-1293.

132.Park JH, et al. Long-term results of spinal cord injury therapy using mesenchymal stem cells derived from bone marrow in humans. Neurosurgery. 2012;70(5):1238-1247

133. Ra JC, et al. Safety of intravenous infusion of human adipose tissue-derived mesenchymal stem cells in animals and humans. Stem Cells Dev. 2011; 20(8):1297-1308. 